ISSN No. 0974-035X

An indexed refereed \& peer-reviewed journal of higher education

Towards Excellence

UGC-HUMAN RESOURCE DEVELOPMENT CENTRE

Gujarat University, Ahmedabad-380009, Gujarat, India

\title{
COMBATING THE IMPACT OF COVID-19 ON HIGHER EDUCATION SECTOR IN INDIA
}

\author{
Ms. Sourovi Thakur \\ Dr. Usashi Kundu (De)
}

\begin{abstract}
On $30^{\text {th }}$ January 2020, India reported its first covid-19 positive case in Kerala and it reached to 100 confirmed cases by mid of March of the same year. Sensing its severity, Prime Minister of India called for voluntary Janta Curfew for 14 hours on $22^{\text {nd }}$ March. As the confirmed cases and death tolls started to increase, from $25^{\text {th }}$ March 2020 lockdown started. Since then education sector from nursery to university level are shut down. About 320 millions of learners are affected by the pandemic in India. This paper is focused on higher education sector only. Higher education in India gets a massive shock as enrolment to new academic year has been postponed, all examinations got withheld, curricular work got hampered, students are facing immense stress of upcoming economic crisis and institutes are facing threats of losing their revenues. Under this situation, the researchers purport to analyse the impact of COVID-19 on higher education sector in India and to look into the possible strategies to combat this situation. Descriptive analytical method has been used in this present study. Different e-journals, websites, articles have been used as secondary source of data. The study highlights on the growing interest in e-learning and usage of various ICT tools in imparting knowledge to the learners. It is revealed that there is a sharp increase in enrolment to MOOCS. Although technological advancement is doing its job to run the teaching-learning process in the higher education sector of India but digital divide is inhibiting a large section of learners to get these benefits. Along with this psychological crisis is also present. Therefore, the technological facilities and infrastructure should be improved in every corner of the country for combating COVID-19 and other such adverse conditions in future.
\end{abstract}

Keywords: Higher education, ICT, MOOCS, digital-divide 


\section{Introduction:}

COVID-19 case was first reported in China in December, 2019. WHO is proving constant update about the global spread of COVID-19 cases and has classified it as a pandemic on $11^{\text {th }}$ March, 2020. Presently 191 countries are affected by the pandemic outbreak of COVID-19. All the sectors of these countries including education got disrupted. The effect of this pandemic on education at global level is being monitored by UNESCO. In India, the Govt. took immediate actions to inhibit the entry and spread of this deadly virus. Until a cure or vaccine of Corona virus is discovered, the best possible measure to be followed is social distancing. On $22^{\text {nd }}$ March Prime Minister of India called for voluntary Janta curfew for 14 hours proceeded by national lockdown from $25^{\text {th }}$ March, 2020. In India all educational institutes, from preschools to universities remain completely closed since $25^{\text {th }}$ March 2020, and eventually about 320 million students are being affected by this pandemic. The need of the time is that government and private institutions must safeguard the 'right to education' without compromising the health of its stakeholders. This is the duty of all the authorities that students must not stop learning despite of the physical closure of the educational institutions (UNESCO IESALC, 2020). It is said that in every crisis there must be some opportunity as well. So first one needs to analyse the crisis situation and then come up with ideas to turn it into opportunity. This is the sole agenda of the current study.

Objectives: The objectives of the paper are:

- To analyse the impact of COVID-19 on higher education sector of India, and

- To look into the possible strategies to combat the threats of COVID-19 in higher education in India.

\section{Methodology of the study:}

To find out the answers of the raised questions, that is, to achieve the objectives of the study, the researchers have employed descriptive and analytical methods. For that purpose various secondary sources of data available over the internet like e-journals, e-articles, websites, online newspapers etc. were studied thoroughly.

\section{UNESCO IESALC report on COVID-19 effect on higher education:}

Under this COVID-19 pandemic, when impact on so many variables of the higher education system are yet to be recognised, IESALC of UNESCO has come up with a concrete and comprehensive guidelines which must be acknowledged. 
- The actual impact of this situation on different stakeholders of higher education sector is very hard to tell as there is no previous reference of similar scenario in the past. So at the same time it is hard to estimate future prospect of higher education.

- Students face the greatest hurdle as face to face teaching learning is suddenly stopped, leaving them clueless about their future.

- Teachers are also heavily affected as they have to transform their teaching from face to face mode to complete online mode.

- There is a high possibility of the non-teaching staff to lose their jobs.

- The two major challenges the higher education is currently facing is to remain academically active and financially sustainable.

\section{Impact of COVID-19 on higher education:}

As the whole world is still searching for a cure or vaccine for COVID-19, social distancing is the only temporary solution that we have. The lockdown in India started on $25^{\text {th }}$ March 2020 and very recently from $8^{\text {th }}$ June 2020 unlock plans have been started. But to safeguard the students and teachers, the education sector is completely shut down till now. Closure of higher education not only have short term effect on the continuity of learning but also have its long term economic, social and psychological consequences.

- The total education system is shut down. As an alternative to face to face mode of teaching-learning, virtual classrooms are being widely used.

- Few online platforms like Zoom app, Google meet, Telegram etc. are being used for conference, lectures, live streaming as a part of knowledge sharing at higher education level. These sessions are now known as Webinars.

- MHRD is motivating for e-learning to keep the continuity of the higher education in the country. Some of the vastly used e-learning platforms are Diksha, E-Pathshala, National Repository of Open Educational Resources, SWAYAM, SWAYAM Prabha, GoogleYouTube Learning Destination, GETCETGo, Moodle App for online teaching-learning etc.

- HRD ministry's SWAYAM is currently offering 574 online course to over 26 lac students. About 1500 courses are there for self-learning. According to the MHRD report, 50 thousands new subscribers enrolled in SWAYAM since the lockdown started. 
- In higher education level, practical work is a major part of the curriculum. Though few universities and organizations are providing virtual labs to their students but they are quite expensive (Harsha \& Bai, 2020).

- As the total education system is working on online mode, it requires a steady and highspeed internet connectivity. A large section of students are using mobile internet. Many parts of India have either no internet connectivity or have very interrupted or slow connectivity. The cost of internet connection is also a huge burden for a large number of students. So digital divide is still there that is hindering the equal access to education under this lockdown.

- Immediate closing down of educational institutes was indeed the need of the time, and for that all the examinations had to be postponed. This might affect the final result as there is a delay between the lesson taught and the terminal examinations (Gupta \& Goplani, 2020). Another affecting agent could be the instability of mind due to all this uncertainty.

- Final year students are under immense stress and anxiety due to uncertainty of their course completion and extension of joining date.

- A large portion of students under higher education stays in hostels, PG, rented homes etc. With the announcement of the lockdown they had to leave immediately and had to go to their native places. In this hurry, many of them failed to carry their books and other essential study materials which eventually disrupted their learning during lockdown.

- A large number of national level, state level, institutional level examinations and recruitment examinations have been either cancelled or postponed.

- Students who are planning to get admission in foreign universities or the foreign students who want to get admission in Indian universities might have to lose one year.

- A large section of Indian students pursuing higher education enrol in foreign universities, in countries like USA, UK, Singapore, Canada, China, Australia etc. As majority of them are badly affected by COVID-19, most of the Indian students are restricted to enter these countries. This trauma in long run may decline the demand of international higher education in future.

- Another threat to higher education is increase in unemployment rate. The Centre for Monitoring Indian Economy highlighted that the unemployment rate which was $8.4 \%$ in mid-March has increased to $23 \%$ in early April; in the urban area the percentage being 30.9\% (Choudhary, 2020). 
- Non-teaching staff are an essential part of higher education sector but unfortunately they are least talked about. To reduce the financial burden the private institutes might curtail their numbers.

\section{Possible strategies to combat the threats of COVID-19 in higher education:}

A multi-faceted strategy is necessary to manage the COVID crisis and also to build a resilient higher education system in India for the long run.

- In the present scenario the teaching-learning has already shifted from traditional face-toface mode to online mode using various ICT tools. But to ensure continuity of learning in colleges and universities, more open-source digital learning solutions and learning management software should be employed so that the teaching-learning can be conducted smoothly in a well-organized manner.

- To reach the most vulnerable and marginalised section of learners a more inclusive learning solution is required. To achieve this target, a rapid increase in internet facilities throughout the country is necessary. Studies suggest that by $2024,85 \%$ households will get mobile internet (Bhalla, 2020). Needless to say mobile based learning models are most effective and user friendly.

- According to Dr. Ashwin Fernandes (Regional Director - Middle East, North Africa and South Asia, QS Quacquarelli Symonds and CEO, QS IGAUGE Rating), in the game of transition from face-to-face mode of education to online based education, India is now at stage 1 where classes are taken online. In stage 2, 100\% course delivery including assessment and grading have to be carried out online. In the final stage 3 online degrees need to be given, that is, total course credits are to be delivered online. He added that to reach stage 3 India requires smooth power supply, steady internet connectivity all around and a robust training of both faculties and students on various educational-tech tools (Murthy, 2020).

- Much effort is needed to prepare the higher education sector to adapt itself with ever changing demand-supply trend, both nationally and internationally. Immediate actions are required to overcome the adverse effect of COVID-19 on job offers and internship programmes.

- Indian traditional knowledge in the field of sustainable technology and medicines is well known all over the world. More research should be encouraged in the fields like Indian medicines, yoga, ethnobotany, agriculture, architecture etc. and these should be integrated 
with mainstream university education to provide more benefit to the humanity (Choudhary, 2020).

- Co-founder of Infosys, Nandan Nilekani gave the idea of physical infrastructure to mitigate the issue of digital divide. He mentioned that a student may not have a device but a digital service centre could be near to him. So the worksheet can be collected and dropped at the centre. The centres can then upload them to the learning portal. Currently Himachal Pradesh is using this strategy (Ujaley, 2020).

- Most of the present day teachers can operate computer and majority of them have the internet facility at home. So instead of calling them to the institute for administrative work, they should be asked to get those work done from home (Bhat, et. al., 2020)

- When practical and skill based knowledge is to be imparted, the session could be demonstrated in the institutional laboratory and recorded or live streamed online for the students.

- More free online course, especially practical courses should be offered by the universities and colleges to its students. One such example is TATA Steel which is offering nearly 27 online courses at Rs. 1 only.

- Instead of complete cancellation of examinations, it should be taken online so that students do not stop learning and the online examination score will motivate them to perform better (Gupta \& Goplani, 2020).

- Blended learning could be introduced in future.

- All faculties should be trained in online mode of teaching and their knowledge should be updated time to time by engaging them in refresher courses.

- One of the most vulnerable aspects is the mental health of all the stakeholders of higher education, especially the students. Anxiety and depression are common phenomenon in this scenario. A counselling cell must be functioning in every institute to help and guide their students and other members to combat this adverse situation and to keep them mentally strong and motivated.

- To make the curriculum of the higher education more responsive to the need of the present situation, environmental and health courses must be included and proper hygiene practice must be strengthened (Toquero, 2020).

COVID-19 might give rise to three complementary types of teaching-learning model for the higher education sector (Sharma, 2020). 
1. Augmented Immersive Residential Programs: This model specifically focuses on social, emotional and intellectual development of the students. Under this model the higher education institutes can provide personal interaction for some part of its courses against a high price.

2. Hybrid Programs: The COVID-19 situation has made us realize that technology can substitute, augment and complement the course curriculum. According to the nature of knowledge to be transferred, an institute can use hybrid of online and in-campus learning mode.

3. Online Programs: Higher education sector can go completely online for few of its courses. The online courses have zero marginal cost that makes it very advantageous, provided that it has to be very involving and engaging.

\section{Conclusion:}

The pandemic attack of Corona virus has turned the higher education system of India upside down. Social distancing and online teaching-learning is the 'New-normal'. A study was conducted by Arora and Srinivasan (2020) in Ghaziabad to assess the benefits of virtual classes in higher education institutes. The result revealed that the actual benefits are significantly less than the expected benefits of virtual classes. Lack of awareness, poor connectivity, and lack of personal touch are the important ones among the causing agents. A panel of educationists on a webinar hosted by ORF's Mumbai Chapter, came to a common conclusion that to revive the higher education sector under this turmoil, strategies should be implemented from four angles, that is, access, pedagogy, teacher-training and collaboration. Along with this Govt. must provide better and cheaper internet connection to its entire citizen. In the opinion of the researchers, a mock drill for this kind of adverse situation should be practised time to time in higher education sector to combat such adverse situation in the future more effectively. To conclude with, COVID-19 can be called as a "Creative Destruction" (Schumpeter, 1942) with respect to higher education in India. This is because, COVID-19 driven lockdown insisted the higher education system to shift to online teaching-learning mode and other digital innovations carried out in higher education level that otherwise might take a little more time to implement at the mass level. 


\section{References}

Arora, A. K., and Srinivasan, R. (2020). Impact of pandemic COVID-19 on the teaching learning process: A study of higher education teachers. Prabandhan: Indian Journal of Management, 13(4), 43-56.

Bhalla, T. (2020, April 28). Amid virus crisis, 87\% business leaders prefer re-skilling over hiring: Report. LiveMint. Retrieved from https:/www.livemint.com/news/india/amid-virus-crisis-87business-leaders-prefer-re-skilling-over-hiring-report-11588092965242.html

Bhat, R., Singh, V. K., Naik, N., Kamath, C. R., Mulimani, P., \& Kulkarni, N. (2020). COVID 2019 outbreak: The disappointment in Indian teachers. Asian Journal of Psychiatry, 50. DOI: 10.1016/j.ajp.2020.102047

Choudhary, R. (2020, April 16). E-learning: COVID-19 pandemic: Impact and strategies for education sector in India. ET Government. Retrieved June 9, 2020, from https://government.economictimes.indiatimes.com/news/education/covid-19-pandemicimpact-and-strategies-for-education-sector-in-india/75173099.

Gupta, A., \& Goplani, M. (2020). Impact of covid-19 on educational institutions in India. Purakala an UGC CARE Journal, 31(21), 661-671.

Harsha, R., \& Bai, T. (2020). Covid-19 lockdown-challenges to higher education. Cape Comorin, 2(4).

Retrieved

from

https://www.researchgate.net/profile/Harsha_Raju/publication/341274523_Covid_-

19_Lockdown Challenges_to_Higher_Education/links/5eb758654585152169c13291/Covid19-Lockdown-Challenges-to-Higher-Education.pdf.

Lockdown Impact: Government's e-learning platforms witness surge in subscribers. (2020. March 29). ETGovernment. Retrieved from https:/government.economictimes.indiatimes.com/news/education/lockdown-impactgovernments-e-learning-platforms-witness-surge-in-subscribers/74870839.

Murthy, A. K. (2020, May 26). Online higher education in India during the COVID-19 pandemic. $O R F$. Retrieved from https://www.orfonline.org/research/online-higher-education-in-indiaduring-the-covid-19-pandemic-66768/. 
Schumpeter, J. A. (1942). Capitalism, socialism and democracy. London: Routledge, UK. 381.

Sharma, V. K. (2020). Navigating the crisis and beyond future of higher education-inpact Covid19. EasyChair.

Toquero, C. M. (2020). Challenges and opportunities for higher education amid the COVID-19 pandemic: The Philippine context. Pedagogical Research, 5(4), DOI: https://doi.org/10.29333/pr/7947

Ujaley, M. (2020, June 08). Covid-19: Reimagining education, digital innovation should be top priority for govt: Nandan Nilekani. ET Government. Retrieved June 9, 2020 from https://government.economictimes.indiatimes.com/news/education/reimagining-educationdigital-innovation-should-be-top-priority-for-govt-nandan-nilekani/76242439.

UNESCO-IESALC. (2020). Coronavirus COVID-19 and higher education: Impact and recommendations. Retrieved from http://www.iesalc.unesco.org/en/2020/03/09/coronaviruscovid-19-and-higher-education-impact-and-recommendations/.

UNESCO-IESALC. (2020, April 09). COVID-19 and higher education: Today and tomorrow: Impact analysis, policy responses and recommendations. Retrieved from http://www.iesalc.unesco.org/en/wp-content/uploads/2020/04/COVID-19-EN-090420-2.pdf

\author{
Sourovi Thakur \\ Ph.D. Scholar \\ Dept. of Education, Diamond Harbour Women's University \\ Sarisha, West Bengal \\ sourovithakur.edu@gmail.com, Mobile: 9836092421 \\ \& \\ Dr. Usashi Kundu (De) \\ Asst. Professor \\ Dept. of Education, Diamond Harbour Women's University \\ Sarisha, West Bengal \\ usashik@gmail.com, Mobile: 9836936970
}

